\title{
The Importance of Biodegradable Waste in Transforming the Economy into a Circular Model in Poland
}

\author{
Marta Szyba*, Justyna Muweis \\ AGH University of Science and Technology, Aleja Adama Mickiewicza 30, 30-059 Kraków, Poland
}

Received: 1 September 2021

Accepted: 30 October 2021

\begin{abstract}
Changes in the approach to using waste as resources will be a necessity in the coming years. It is due to the transformation of the linear economy into a circular model and many regulations concerning waste management in the European Union countries. The article deals with the important issues of segregation and management of biodegradable waste, which are still unused energy potential. The aim of the study was to investigate the amount of this fraction of waste generated by sample households as well as the problems and barriers related to their storage and collection. The article takes into account the economic, environmental and social conditions that constitute the basis of sustainable development and are very significant for the idea of the circular economy. The minimizing and proper management of the fraction of municipal and biodegradable waste could achieve a greater economic benefits with simultaneous benefits for the environment, protecting its components and human health.
\end{abstract}

Keywords: circular economy, municipal waste segregation, biodegradable waste, biogas plants

\section{Introduction}

Due to the growing population and consumption lifestyle, the amount of municipal waste is increasing in all developed countries. The change in the economic system in 1990 and the preparation of Poland for accession to the European Union made it necessary to create a municipal waste management system, including: collecting, transporting, processing and supervising all tasks. The basis for the proper functioning of the system is selective collection of waste at its source. Selective collection facilitates the recovery of such raw materials

*e-mail:mszyba@zarz.agh.edu.pl from waste as: metals, glass, plastics and paper, and the destination of the remaining ones for thermal and biological disposal and at last for disposal in landfills. Collecting mixed fractions of waste makes it necessary to segregate them before further processing, which reduces the economic efficiency of the system.

The biggest problem is collecting biodegradable household waste - especially kitchen waste - together with other fractions. They pollute other fractions and, undergoing rapid decomposition, pose a threat to people and the environment. Separate collection of municipal biodegradable waste allows for its mechanical and biological processing and, depending on the method used, to produce compost or biogas and digestate [1]. In this way, the risks associated with the uncontrolled decomposition of organic substance are eliminated and 
the sale of products remaining after processing reduces the costs of the waste management system.

When decomposing, organic waste releases gases which is used to build installations called biogas plants [2]. In biogas plants with the participation of mesophilic bacteria takes place a process of decomposition of substrates, called anaerobic fermentation. As a result of this process, biogas is produced, which is a renewable energy source (RES). Biogas is also produced in landfills, in wastewater treatment plants or in the socalled agricultural biogas plants. The biogas produced latter is called agricultural biogas and its producers are awarded "blue certificates".

The article focuses on the issues of municipal biodegradable waste segregation (codes 200201 and 200108 ) and the possibility of using them for biogas production. The aim of the study was to investigate this fraction of waste generated by sample households and to formulate proposals limiting the problems related to their storage and collection.

\section{Experimental}

\section{Methodology}

The following research methods were used in the research: review and analysis of legal acts and scientific literature; analysis of data published by the Central Statistical Office and analysis of data obtained from the Energy Regulatory Office. The effects of the applicable act on waste management and order planning in communes were presented. Despite the meta-analysis, proprietary research was carried out, consisting in collecting and weighing kitchen and mixed waste generated in two households, representing two forms of residence in Poland. One of them is an apartment in a single-family building, the other in a multi-family building. The aim of the research was to identify problems related to the collection of kitchen waste and its collection in a condition suitable for use in biogas plants. The research results are presented in charts made in Excel.

\section{Municipal Waste Management}

Writing about municipal waste management in Poland, one cannot ignore the background of waste management in the European Union. It is shaped by successive waste directives that set goals to be achieved. For example, the recycling rate of packaging waste is expected to reach $65 \%$ in 2025 and increase to $70 \%$ in 2030 [3].

The waste management regulations in the EU are based on the regulations of the European Commission. The basis is Directive 2008/98/EC of 19 November 2008 on waste and repealing certain directives. The aim of the mentioned directive is to protect the environment and human health by determining appropriate waste management and specifying recovery and recycling techniques. In addition, this document emphasizes the minimization of the demand for natural resources and their optimal use. The waste hierarchy in the directive covers: prevention, re-use, recycling, other recovery methods and disposal [4].

Under the new circular economy model, waste becomes a valuable resource that is recycled into the product life cycle. In this model, landfilling becomes finality that is abandoned. This approach is aimed at minimizing waste in the economy, using the existing ones in various ways, creating integrated and sustainable business models combining economic, environmental and social goals [5].

The transformation of a linear economy into a circular economy will be the path to sustainable development in the coming decades and will be a priority in the environmental policies of the Member States. Its objectives will be implemented through a number of legal regulations, guidelines and the use of appropriate instruments tailored to specific problems occurring in the broad sense of waste management.

The effects of implementing the adopted waste management concept in 1995-2019 are shown in Fig. 1. Between 1995 and 2005, the amount of municipal waste increased from 198 million $\mathrm{Mg}$ to 221 million $\mathrm{Mg}$. This growth was probably influenced by the admission of ten new members to the EU in 2004, including Poland. In 2015, the amount of municipal waste decreased to $214 \mathrm{Mg}$. In 2019, the amount of this waste increased to $221 \mathrm{Mg}$, i.e. by $11.6 \%$ compared to the base year 1995. In the discussed period, the proportions between various methods of waste management changed significantly. While in 1995 landfilled waste constituted $61.1 \%$, in 2019 their amount decreased to $23.7 \%$. In 1995 , only 26 million $\mathrm{Mg}$, ie $11.6 \%$, was recycled, which is the best form of waste utilization, as it returns valuable raw materials to circulation. In 2019, 68 million $\mathrm{Mg}$ was recycled, which accounted for $30.4 \%$ of all waste. Similar changes concerned waste disposal $(15.2 \%$ and $26.8 \%)$ and composting (7.1\% and $17.4 \%)$.

In Poland, after 1990, municipal waste was practically entirely disposed of in landfills, from which groups of collectors obtained mainly metal scrap. The Waste Act of 27 June 1997, along with the Act on maintaining cleanliness and order in municipalities, created the foundations of a waste management system. These laws have been amended many times to conform to the EU guidelines.

Due to the Act of December 14, 2012, waste can be defined as any substance or object that the holder discards, intends to discard or is required to dispose of. Waste includes municipal waste generated in households, excluding end-of-life vehicles, as well as waste not containing hazardous waste from other waste producers, which due to its nature or composition is similar to household waste. Bio-waste is part of municipal waste. These are biodegradable waste 


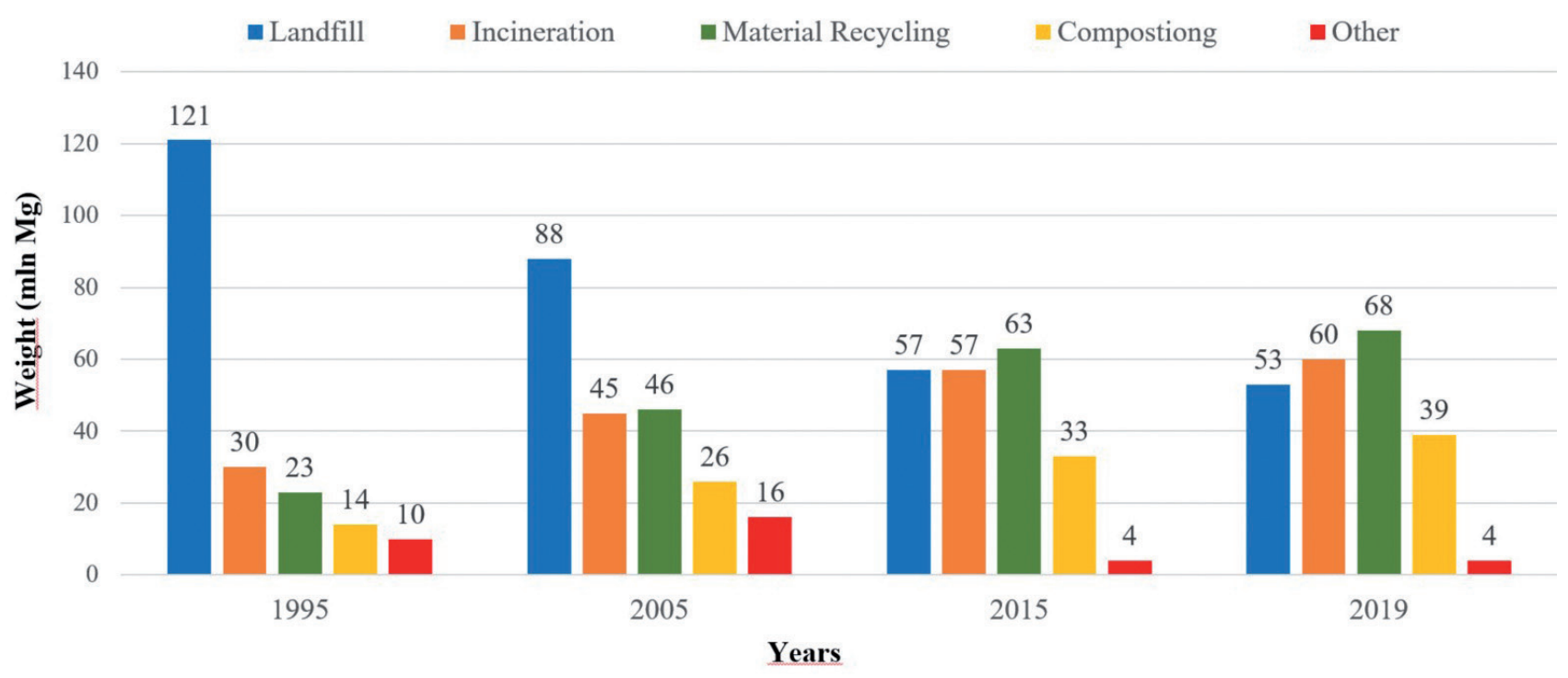

Fig.1. Municipal waste stored, incinerated, recycled and composted in the EU-27 in selected years from the period 1995-2019. Source: [6].

from gardens and parks, food and kitchen waste from households, catering establishments, caterers, retail units, as well as comparable waste from establishments producing or marketing food. These groups of waste are produced by waste producers, i.e. anyone whose activity or existence causes their generation and anyone who carries out preliminary treatment, mixing or other activities that change the nature or composition of this waste [7].

The generated waste has been divided into groups, subgroups and types, which are marked with codes. Their full list can be found in the Regulation of the Minister of Climate of January 2, 2020 on the waste catalog. Municipal waste together with selectively collected fractions constitute group 20 in the catalog. In this group, mixed municipal waste is marked with the code 2003 01, biodegradable municipal waste - green with the code 2002 01, and kitchen waste 200108 [8].

One of the most important regulations on waste management is the Act on maintaining cleanliness and order in municipalities of September 13, 1996, as amended. Its significant change, which had a significant impact on waste management in Poland, took place in 2013. The purpose of the changes was, inter alia, to tighten the municipal waste management system, to conduct selective collection of municipal waste "at the source", to reduce the amount of municipal waste, including biodegradable waste sent to landfills, to conduct proper monitoring and handling of municipal waste by property owners, and entities operating in the field of municipal waste collection. The act also gave municipalities the opportunity to pursue a rational policy with regard to setting fees for collecting municipal waste from property owners and managing this waste. Currently, its version is in force after another modification - the Act of 17 December 2020 amending the Act on maintaining cleanliness and order in municipalities and certain other acts [9]. Therefore the scope of the act has changed. The current version aims to improve the situation of local government units in waste management, in particular in terms of cost reduction. The Act defines both the tasks and obligations of municipalities and property owners regarding the maintenance of cleanliness and order, but also regulates the obligations of certain people in multifamily housing. The obligations of entities generating waste, regardless of whether they are the owners of the property, were also specified [9].

The Segregation System has been in force in Poland since 2017. The deadline by which all municipalities are required to replace waste containers with appropriate colours, adapted to the new system, is June 30, 2022. According to the Unified Waste Segregation System, the following fractions will be applied: bio-waste, paper, glass, metals and plastics, and mixed municipal waste. Municipalities will decide on the division of containers for segregation of glass into white and coloured or will remain with a container for mixed glass [10].

It can be noticed that despite of the introduction by municipalities of the current Unified Waste Segregation System, there are many irregularities in the problems related to its functioning. One of them is improper collection of waste by established companies providing this type of services, another is related to improper segregation of waste by residents. Enterprises that deal with waste processing notice the lack of proper segregation and the appearance of a large amount of mixed waste. The negligence of segregation reduces the levels of recycling and reuse. Such actions distract from the requirements of rational waste management promoted by the European Union in all Member States. 


\section{Municipal Bio-Waste and Methods of Its Management}

The assumption of the circular economy is to reduce the mass of waste, including biodegradable waste, sent to landfills. The main obstacle here are mixed fractions, which, due to their composition, must be disposed of in Regional Waste Processing Facilities (RWPF). Defining this type of organization changes in comparison with the initial regulation of the scope of its activities, defined by the Act of April 27, 2001, Environmental Protection Law - Art. 143. Currently, RWPF is a unit that may have a much wider scope of activities, including it may have installations for innovative municipal waste treatment and other available innovative technologies of mechanical and biological waste treatment [11].

Among municipal waste, biodegradable waste is a direct threat to the environment due to the emission to the atmosphere of methane, which is a greenhouse gas with a carbon dioxide equivalent, human health and comfort of life. The definition of this waste fraction is included in Art. 3 par. 1 point 1 of the Waste Act. The biodegradable waste includes: park and garden waste, kitchen and food waste from households, all kinds of gastronomy, catering units and food production plants, and thus producing related waste [12]. From July 1, 2017, the ordinance of the Minister of the Environment required all communes to collect biodegradable municipal waste separately. It was introduced in order to facilitate the biological treatment of this waste and thus limit its storage in landfills [13]. In multi-family buildings, this waste must be collected in separate brown containers and in single-family buildings in bags of this colour [7].

Table 1 presents data on the amount of collected biodegradable waste from households in 2013, 2016 and 2020. It shows that their amount systematically increased even in the period 2013-2016, when individual municipalities did it voluntarily. For the whole country, the amount of selectively collected biodegradable waste increased from 226,626.4 Mg in 2013 to $1,520,083 \mathrm{Mg}$ in 2020 . This means dynamics at the level of $671 \%$. The dynamics varied considerably in individual voivodships. The highest was in the Podlaskie Voivodeship 2,501\% and the lowest in Warmińsko-Mazurskie 181\%.

In the same period, the amount of municipal mixed waste collected was as follows: in 2013 it was $6,110,131 \mathrm{Mg}$, in 2016 was $6,943,287 \mathrm{Mg}$ and in 2020 was $6,684,917 \mathrm{Mg}$, which means a dynamics of $109 \%$. Biodegradable waste can be methane fermented, composted or incinerated. The first five groups, i.e. coffee grounds, egg shells, expired vegetables and fruits, vegetable and fruit peels, can be subjected to both methane fermentation and composting. The rest, ie plant clippings, cut branches, grasses and leaves, are best composted. Composting is a simple process carried out in piles to produce compost that is an organic fertilizer. Methane fermentation is carried out in specially built installations, called biogas plants.
As a result of fermentation, biogas and digestate are obtained, which is a full-value organic fertilizer [7].

Biogas is a renewable energy source (RES). Methane separated from biogas can be injected into the natural gas network, used for propulsion of vehicles, and after steam reforming it can be a raw material for hydrogen production. However, the most common way of using biogas is its combustion in the combined heat and power (CHP) process generating electricity and heat [2]. This way of using biogas is popular in many EU countries, including Poland.

\section{Biogas Production in Poland}

In Poland, biogas is produced in landfills, sewage treatment plants or in biogas plants producing so-called „Agricultural biogas". It does not differ in composition from biogas from other sources and its name is related to the substrates from which it is produced. In the program „Directions for the development of agricultural biogas plants in Poland in 2010-2020" it was defined as: „fuel obtained in the methane fermentation process from agricultural raw materials, agricultural byproducts, liquid or solid animal excrements, by-products or residues from the processing of agricultural products or forest biomass, excluding gas obtained from raw materials from sewage treatment plants and landfills, [15]. The substances mentioned in the definition are called substrates.

By the end of 2020, 105 agricultural biogas plants were in operation in Poland with a total capacity of over $112 \mathrm{MW}$. These were installations with an average capacity of just over $1 \mathrm{MW}$. They produced 478.44 million $\mathrm{m}^{3}$ of biogas, from which 20,941.30 GWh of electricity was generated. The largest number of biogas plants is located in the following voivodships: Zachodniopomorskie (13), Wielkopolskie (12) and Warmińsko-Mazurskie (12). The smallest number of biogas plants was in the following voivodships: Świętokrzyskie (1), Opolskie (1), Małopolskie (2) and Śląskie (2) [16].

In this type of biogas, production plants use substrates that are waste from the agri-food industry in the form of animal manure, waste from agricultural production, fruit and vegetable processing, or can be grown specifically for a substrate, such as corn and grass silage. The obtained biogas contains large amounts of methane, which is burned in cogeneration units (CHP - Combined Heat and Power technology), resulting in the generation of electricity and heat. Electricity is transferred entirely to the national grid, and heat is used on site to heat residential and farm buildings and to maintain the fermentation process in the biogas plant. It can also be sold to external recipients, such as residential buildings, shops, educational establishments, recreational facilities or offices, if they are relatively close to the biogas plant [17].

The development of the construction of agricultural biogas plants was to be supported by the investment 
Table 1. The amount and dynamics of collected municipal biodegradable household waste in 2013, 2016 and 2020 in Poland, in total and in individual voivodships.

\begin{tabular}{|c|c|c|c|c|c|}
\hline \multirow{2}{*}{\multicolumn{2}{|c|}{ Voivodship }} & \multicolumn{3}{|c|}{ Years } & \multirow{3}{*}{$\begin{array}{c}2020 / 2013 \\
-\end{array}$} \\
\hline & & \multirow{2}{*}{$\begin{array}{c}2013 \\
15605.3\end{array}$} & \multirow{2}{*}{$\begin{array}{c}2016 \\
59608.1 \\
\end{array}$} & \multirow{2}{*}{$\frac{2020}{116152.11}$} & \\
\hline & amount $[\mathrm{Mg}]$ & & & & \\
\hline 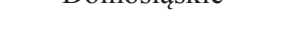 & dynamics [\%] & 100 & 382 & 195 & 745 \\
\hline \multirow{2}{*}{ Kujawsko-pomorskie } & amount $[\mathrm{Mg}]$ & 24958.0 & 51917.5 & 95743.02 & - \\
\hline & dynamics [\%] & 100 & 208 & 184 & 383 \\
\hline \multirow{2}{*}{ Lubelskie } & amount $[\mathrm{Mg}]$ & 8626.3 & 25358.9 & 76163.68 & - \\
\hline & dynamics [\%] & 100 & 294 & 300 & 882 \\
\hline \multirow{2}{*}{ Lubuskie } & amount $[\mathrm{Mg}]$ & 4615.9 & 24789.1 & 39811.77 & - \\
\hline & dynamics [\%] & 100 & 537 & 161 & 865 \\
\hline \multirow{2}{*}{ Łódzkie } & amount $[\mathrm{Mg}]$ & 11753.7 & 41138.2 & 99978.26 & - \\
\hline & dynamics [\%] & 100 & 350 & 243 & 851 \\
\hline \multirow{2}{*}{ Małopolskie } & amount $[\mathrm{Mg}]$ & 13192.3 & 61796.5 & 127772.42 & - \\
\hline & dynamics [\%] & 100 & 468 & 207 & 969 \\
\hline \multirow{2}{*}{ Mazowieckie } & amount $[\mathrm{Mg}]$ & 30996.8 & 75210.9 & 214573.09 & - \\
\hline & dynamics [\%] & 100 & 243 & 285 & 693 \\
\hline \multirow{2}{*}{ Opolskie } & amount [Mg] & 2953.5 & 23668.1 & 45776.28 & - \\
\hline & dynamics [\%] & 100 & 801 & 193 & 1546 \\
\hline \multirow{2}{*}{ Podkarpackie } & amount [Mg] & 4648.3 & 13801.5 & 29644.00 & - \\
\hline & dynamics [\%] & 100 & 197 & 215 & 424 \\
\hline \multirow{2}{*}{ Podlaskie } & amount $[\mathrm{Mg}]$ & 1596.3 & 12325.6 & 39906.79 & - \\
\hline & dynamics [\%] & 100 & 772 & 324 & 2501 \\
\hline \multirow{2}{*}{ Pomorskie } & amount [Mg] & 18043.7 & 64847.8 & 133278.62 & - \\
\hline & dynamics [\%] & 100 & 359 & 206 & 739 \\
\hline \multirow{2}{*}{ Śląskie } & amount $[\mathrm{Mg}]$ & 38756.2 & 159895.0 & 226081.85 & - \\
\hline & dynamics [\%] & 100 & 413 & 141 & 582 \\
\hline \multirow{2}{*}{ Świętokrzyskie } & amount $[\mathrm{Mg}]$ & 696.6 & 3864.1 & 13590.64 & - \\
\hline & dynamics [\%] & 100 & 554 & 352 & 1950 \\
\hline \multirow{2}{*}{ Warmińsko-mazurskie } & amount $[\mathrm{Mg}]$ & 18365.8 & 18721.2 & 33150.89 & - \\
\hline & dynamics [\%] & 100 & 102 & 177 & 181 \\
\hline \multirow{2}{*}{ Wielkopolskie } & amount $[\mathrm{Mg}]$ & 21136.8 & 63029.5 & 165781.81 & - \\
\hline & dynamics [\%] & 100 & 298 & 263 & 784 \\
\hline \multirow{2}{*}{$\begin{array}{l}\text { Zachodnio } \\
\text { pomorskie }\end{array}$} & amount $[\mathrm{Mg}]$ & 10680.9 & 28542.4 & 62677.68 & - \\
\hline & dynamics [\%] & 100 & 267 & 220 & 587 \\
\hline \multirow{2}{*}{ Polska } & amount [Mg] & 226626.4 & 728514.4 & 1520083 & - \\
\hline & dynamics [\%] & 100 & 321 & 209 & 671 \\
\hline
\end{tabular}

Source: Own study based on [14] 
support system in the form of subsidies and low-interest loans, and from 2016, „Green certificates” applicable to all RES installations, were replaced with „Blue certificates, which had a higher price. This, combined with the change of the auction system, increased the profitability of investing in biogas plants. Despite these incentives, few agricultural biogas plants are being built. According to investors, this process is hindered by the issue of permits, agreements, opinions and other acts in the area of spatial planning and development, environmental protection or construction law [18].

\section{Results and Discussion}

\section{Production of Biogas from Biodegradable Municipal Waste}

It is estimated that in 2011 around 1.3 billion tons of kitchen waste were generated worldwide, and this amount is constantly growing. In the interests of the environment and society, kitchen waste management has become important in waste management. Efficient management involves the disposal of this fraction of waste in an ecological manner and in accordance with the principles of sustainable development [19].

Traditional methods of recycling biodegradable waste consist only in neutralizing them. Therefore, the process of anaerobic decomposition of organic matter is used, the effect of which is the production of biogas and digestate. Selected municipal waste, such as household kitchen waste, restaurant waste and expired food, can be successfully used as substrates in biogas plants. The biogas obtained from them has a high methane content [20]. Contrary to other fractions, biodegradable waste of food origin is characterized by biochemical diversity (heterogeneity) and therefore it is a good material for anaerobic treatment. It is caused by a relatively high concentration of proteins, carbohydrates, fats and the lack of heavy metals. Thanks to these features, food waste has the greatest biogas potential compared to other waste. During anaerobic digestion, $100-200 \mathrm{~m}^{3}$ of biogas can be produced per 1 $\mathrm{Mg}$ of food waste [21]. Assuming that biogas contains $60 \%$ methane, it means the possibility of producing $60-120 \mathrm{~m}^{3}$ of fuel with the parameters of high-methane natural gas from $1 \mathrm{Mg}$ of waste. Assuming that $50 \%$ of biodegradable waste collected in 2020 (see Table 1) was kitchen waste, potentially the equivalent of 45.6-91.2 million $\mathrm{m}^{3}$ of natural gas can be produced.

Polish regulations, which clearly define what may be a substrate for agricultural biogas plants, do not include biodegradable municipal waste, which is kitchen waste (code 200108 ) [22]. According to the act, kitchen waste includes: food scraps (excluding meat), fruit and vegetable peelings and skins, expired fruit and vegetables, egg shells, unused bakery products, coffee and tea grounds, green waste, including paper coffee filters [23]. In agricultural biogas plants, waste specified in the Act can be utilized, thus becoming installations that fit into the area of closed-loop management. The introduction of the possibility of using kitchen waste as substrates for the production of agricultural biogas could contribute to an increase in the number of agricultural biogas plants in Poland. They would be created in suburban areas, around large cities, constituting a source of renewable energy and a place for safe disposal of biodegradable waste generated in cities and suburban areas.

An alternative solution for agricultural biogas plants would be Danish technology, i.e. centralized anaerobic digestion plants (CAD). Centralized biogas plants use waste generated in their area, such as manure, slaughterhouse waste, sewage sludge, biodegradable waste from households and various types of waste from the food industry. The owners of such plants are agricultural cooperatives. Such installations are located close to cities, as they produce electricity and heat supplied to the power and heating networks, respectively. Due to the location near cities, the highest standards of environmental protection and odor nuisance control must be maintained. Substrates are stored in airtight tanks and sterilized or pasteurized before transhipment, by means of a sealed installation, to the fermentation chambers. All the air in the system passes through the odor filters and the plants built with the latest technology are completely closed and all odors are removed by chemical processes [24].

In Poland, such biogas plants should be built in the areas of large municipalities, which would be investors, because they are more expensive to build than agricultural biogas plants. The use of substrates in the form of kitchen and agrifood waste allows to increase profitability, enabling economic activity in Poland, where subsidies are lower than, for example, in Germany or Austria. Equally important benefits are energy production, allowing to achieve the mandatory share of renewable energy in the national energy mix for 2030. The target set by the EU is $32 \%$ and the achievement of the goals set out in the European Green Deal, such as greenhouse gas emissions to at least $55 \%$ by 2030 from 1990 levels, transition to a circular economy and improvement in energy efficiency by at least $32.5 \%$ [25].

In order to identify problems related to the collection of municipal biodegradable waste in the period October 2020 - March 2021, biodegradable and mixed waste was systematically weighed in two households that conduct selective collection of municipal waste. In the first household, there were three adults living in a singlefamily house with its own dumpster shelter. The shelter is large enough to accommodate a rack for bags in which glass, plastics and metals, paper and glass are collected once a month. There is also a mixed waste container in the shelter. Biodegradable waste from garden care is collected in a brown bag stored separately. Kitchen waste is collected in a brown bag, which is placed 
in a closed metal container to protect against rodents. Mixed waste and kitchen waste were weighed before collection. Mixed and biodegradable waste is collected every 2 weeks. It is too rare, especially when the temperatures are high, which accelerates the rotting and molding of the waste.

In the second household, waste was generated by two adults living in a multi-family building in one of the Krakow estates. The apartment segregated waste (mixed waste, biodegradable waste, plastic, metal, glass and paper). The waste was thrown into containers placed in the dumpster shelter located next to the building. The capacity of the containers was too small in relation to the amount of waste generated by the inhabitants. Therefore, instead of being placed in containers, waste was thrown close to them. The lack of proper segregation and placing individual fractions in the wrong containers was noticed. The biodegradable waste container is too small in relation to the amount of biodegradable waste generated. Large amounts of this waste are produced by the inhabitants of the ground floor apartments with their own gardens. More green waste is generated in them than in flats on the upper floors. The container for biodegradable waste in the dumpster shelter is not adapted to the collection of green waste from gardens. As a result, such waste is dumped in a mixed waste container. Fig. 2 shows how the amounts of mixed and kitchen waste per person developed in the period from October 2020 to March 2021. Looking at the graphs, you can see that there are differences in the amount of waste collected in individual months.

In household 1, the amount of mixed waste collected per person was almost constant and did not exceed $2 \mathrm{~kg}$.
This is due to the fact that in this household only dairy products are purchased in factory packaging, which, after emptying, are washed in the dishwasher and put in bag for plastic and metal waste. The amount of kitchen waste was greatest in October, as a small amount of fruit and vegetable preserves was made.

In the household 2, the amounts of mixed waste and kitchen waste changed throughout the year. This was due to the situation related to the renovation of the apartment and the removal of plants (flowers and vegetables) on the large terrace belonging to the apartment. October 2020 was the month of producing biodegradable waste both from the balcony and from preserves made at that time for the winter. The use of fruits and vegetables gave large amounts of fruit and vegetable peels. The last months of 2020 in household 2 were devoted to renovation. A lot of mixed waste was created then, which did not qualify for segregation. The months from January to March showed stabilization and there were slight differences in the amounts of both biodegradable and mixed waste.

The Impact Of Biodegradable Waste On Sustainable Development - Economic, Social and Environmental Aspect

Biodegradable waste is an important area of the waste management system both in the European Union and in individual Member States. In Poland, the problem of selection, collection and management of biodegradable waste is a big challenge both in terms of organization, administration and technology. Unfortunately, despite the large potential of this fraction of waste, there are barriers to its management.

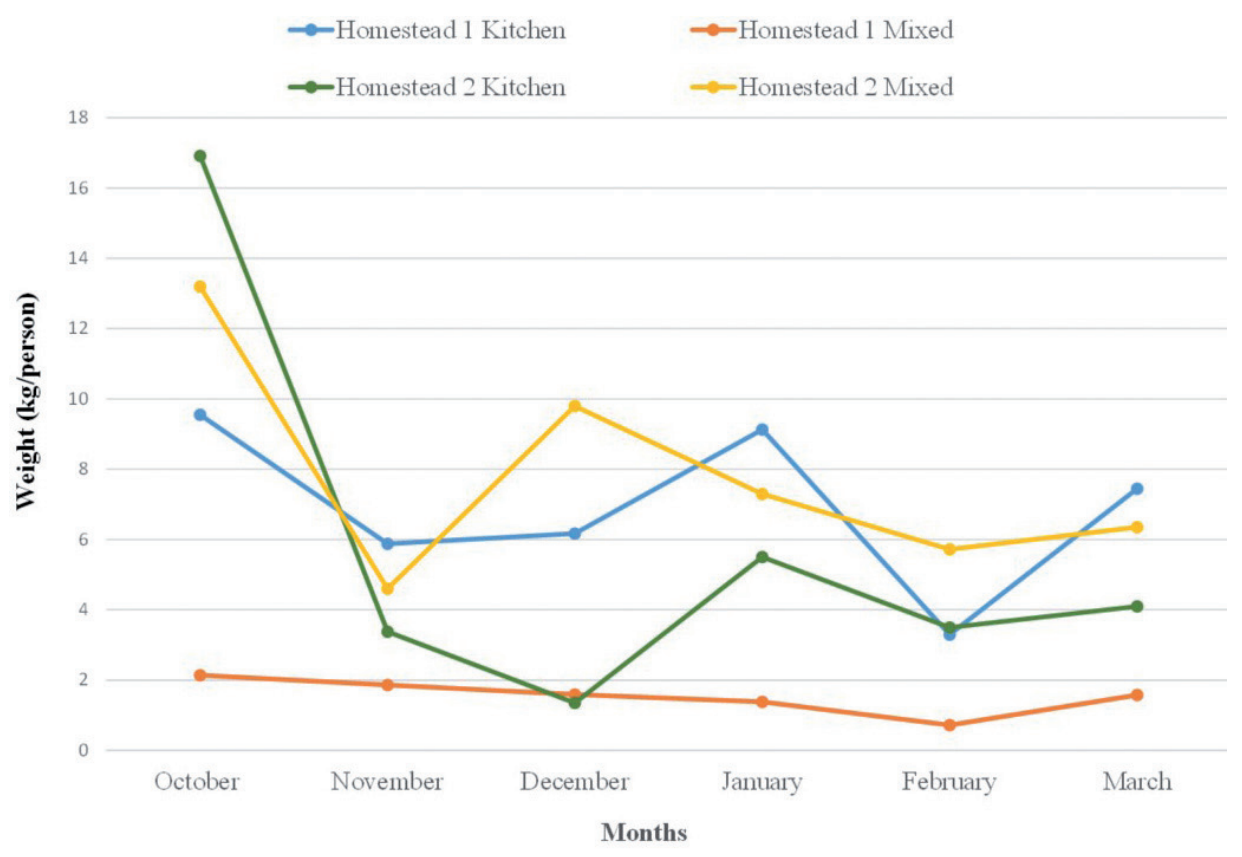

Fig. 2. Amount of mixed and kitchen waste collected per person from households 1 and 2 in the period from October 2020 to March 2021. 
Difficulties arise for the waste generating entities themselves, as well as for the local administration.

The use of biodegradable waste includes in the goals and directions of sustainable development [ 26]. The issues raised in the article concern environmental, economic and social aspects. Changes in waste management are necessary both on a macro and a micro scale. The United Nations Development Program distinguishes as many as 17 sustainable development goals set by 2030 [27]. The subject of the work is based on several of them. The social aspects include the acquisition of knowledge and skills needed to promote sustainable development, for example through education for sustainable development and a sustainable lifestyle and the transfer of knowledge about proecological solutions used by waste management entities. Therefore, more effective environmental education and increasing public awareness will be of key importance for the acquisition and more effective management of biodegradable waste. Another environmental and economic goal is clean and available energy. This is related to ensuring universal availability of stable, sustainable and modern energy sources at an affordable price. Hence, it is planned to significantly increase the share of renewable energy sources in the global energy mix to $32 \%$ by 2030 [28].

Biogas obtained from biodegradable waste is one of the examples of solutions that meet these criteria. The undisputed environmental benefits include increasing the use of renewable energy sources, and thus the elimination of fossil fuels used for energy production. Additionally, it favors the development of sustainable consumption and production models. The amount of municipal waste generated by its citizens is often used to measure the level of consumerism in a given region's society. If more biodegradable waste, which is often not separately collected for various reasons, could be obtained, it would be possible to achieve a greater economic benefit with simultaneous benefits for the environment, protecting its components against pollution to a greater extent and reducing the use of non-renewable resources. Such measures contribute to a higher level of protection of human health and the functioning of ecosystems, and can contribute to intergenerational fairness, taking into account the use of natural resources.

\section{Conclusions}

Biodegradable waste plays an important role in creating a recycling society. The necessity to transform the economy from linear to circular model will force waste managers to treat them as resources. Possibilities of obtaining biogas from biodegradable waste can be an alternative to energy production from fossil fuels. The problems that arise in connection with this fraction of waste already concern the stage of segregation, storage and their storage in dumpster shelter.
In many households, this fraction is often not segregated due to the convenience and lack of space for appropriate containers. However, the research results show that this fraction shows great potential.

The study carried out in two households shows that the variability in the amount of mixed waste of the analyzed fractions was connected with the variability of the seasons and the situation in households, e.g. renovation. In autumn, large amounts of vegetables and fruit were used, and preserves were made for the winter. In addition, due to the large terrace belonging to the apartment, green waste appeared as increased amount in the autumn months because it was put in order. In a single-family house, green waste was collected in a separate brown bag, while in a flat, green waste was thrown together with kitchen waste into a brown container in a dumpster shelter, due to the lack of any other possibility of segregation.

Observation of the practice of segregating waste and its collection, made the following conclusions:

- residents of single-family houses have better options for selective waste collection, with particular emphasis on kitchen waste,

- in multi-family buildings, the dumpster shelter has too few containers in relation to the amount of waste generated in the periods between consecutive collection dates, there is no separate paper container (it is mixed with plastic and metal waste),

- there is too small glass container in a multi-family building,

- if it is not possible to reconstruct the shelters, the frequency of collection should be increased and adjusted to seasonal fluctuations in the amount of generated waste (e.g. in the pre-holiday periods),

- biodegradable kitchen waste must be collected in closed containers in order to protect against rodents and odor,

- the storage time of biodegradable kitchen waste to be subjected to methane fermentation must be short in order to prevent the growth of mold and other processes that will reduce its efficiency,

- no registration obligation and the use of houses not collected by the Poviat Building Inspectorates, does not allow for the precise determination of the number of waste producers in each premises, which forces local governments to link the fees for waste disposal with the area of the premises or the amount of water used.

\section{Conflict of Iterest}

The authors declare no conflict of interest.

\section{References}

1. WĄSOWICZ K., FAMIELEC S., CHEŁKOWSKI M. Gospodarka odpadami komunalnymi we współczesnych 
miastach (Municipal waste management in modern cities), Publisher: Fundacja Uniwersytetu Ekonomicznego w Krakowie, Poland, 13, 2018.

2. KANITAS V., MARCIUKAITIS M., PEREDNIS E., \& DZENAJAVICIENE E.F. Analysis of biodegradable waste use for energy generation in Lithuania, Renewable and Sustainable Energy Reviews, 101, 559, 2019. doi: 10.1016/j. rser.2018.11.022

3. DIRECTIVE (EU) 2018/851 OF THE EUROPEAN PARLIAMENT AND OF THE COUNCIL of 30 May 2018 amending Directive 2008/98/EC on waste https://eurlex.europa.eu/legal-content/EN/TXT/PDF/?uri=CELEX:3 2018L0851\&rid $=5$.

4. DIRECTIVE 2008/98 / EC of 19 November 2008 on waste and repealing certain directives.

5. COMMUNICATION of 25 September 2014 "Towards a Circular Economy: A program - Zero Waste for Europe".

6. https://ec.europa.eu/eurostat/statistics-explained/index. php?title=Municipal_waste_statistics\#Municipal_waste_ generation (accessed on 7 July 2021).

7. ACT of December 14, 2012 on waste (Journal of Laws of 2013, item 21), as amended d.

8. REGULATION OF THE MINISTER OF CLIMATE of 2 January 2020 on the waste catalog, Journal of Laws No. 2020 item 10.

9. ACT of December 17, 2020 on the amendment to the act on maintaining cleanliness and order in municipalities and some other acts. Journal of Laws December 28, 2020 Item 2361.

10. https://www.prawo.pl/samorzad/segregacja-smieci-zasadyjakie-odpady-do-jakich- kolorow,347745.html (accessed on 27 July 2021).

11. MUWEIS J., Using the municipal waste for the alternative fuels production on the example of an enterprise operating with pro-ecological installation. Innowacje młodych naukowców a cele zrównoważonego rozwoju/red. nauk. Olga Janikowska, Instytut Gospodarki Surowcami Mineralnymi i Energią PAN. - Kraków: Wydawnictwo IGSMiE PAN, 107, 2020.

12. JAGUSTYN B., WASIELEWSKI R., SKAWIŃSKA A. Basics of classification of biodegradable waste as biomass. Environmental Protection, 36 (4), 45, 2014.

13. REGULATION OF THE MINISTER OF THE ENVIRONMENT of 15 December 2017 on the levels of limitation of the storage of biodegradable municipal waste mass (Journal of Laws of 2017, item 2412.

14. https://bdl.stat.gov.pl/BDL/dane/podgrup/ temat/13/185/1675 (accessed on 21 July 2021).
15. DOCUMENT OF THE COUNCIL OF MINISTERS of 13 July 2010 entitled Directions of development of agricultural biogas plants in Poland in 2010-2020). https://www.pigeor. $\mathrm{pl} / \mathrm{media} / \mathrm{js} / \mathrm{kcfinder} / \mathrm{upload} /$ files/Kierunki-RozwojuBiogazowni-Rolniczych-w-Polsce-na-lata-2010-2020.pdf (accessed on July 20 July 2021).

16. ENERGY REGULATION OFFICE, Department of Social Communication - letter DSK-056-29 (4) / 2021 / IRŚ of April 1, 2021).

17. SZYBA M. Spatial planning and the development of renevable energy sources in Poland. Acta Innovations, 39, $5,2021$.

18. OSROWSKA A. Legal and administrative barriers to the construction of agricultural biogas plants in Poland, Acta Universitatis Lodziensis - Folia Oeconomica, 270 (2012), 127, 2012.

19. SAHU N., SHARMA A., MISHRA P., CHANDRASHEKKAR B., SHARMA G., KAPLEY A., PANDEY R.A. Evaluation of biogas production potential of kitchen waste in the presence of spices, Waste management, 70, 236, 2017.

20. MARKS S., DACH J., FERNANDEZ MORALES F. J., MAZURKIEWICZ J., POCHWATKA P., GIERZ Ł. New trends in substrates and biogas systems in Poland, Journal of Ecological Engineering, 21 (4), 2020.

21. STUNZENAS E., KLIOPOVA I., Optimizing municipal biodegradable waste management system to increase biogas output and nutrient recovery: a case study in Lithuania. Energy Procedia, 147, 641, 2018.

22. REGULATION OF THE MINISTER OF CLIMATE of 2 January 2020 on the waste catalog, Journal of Laws No. 2020 item 10).

23. https://naszesmieci.mos.gov.pl/jak-segregowac/15-pytaniai-odpowiedzi/segregacja/20-co-nalezy-wrzucac-dopojemnika-na-odpady-biodegradowalne (accessed on 20 July 2021).

24. https://www.gramwzielone.pl/bioenergia/10699/dlaczegobiogazownie-przynioslyby-polsce-ogromne-korzysci (accessed on 20 July 2021).

25. https://ec.europa.eu/clima/policies/strategies/2030_pl. (accessed on 20 July 2021).

26. https://www.un.org.pl/ (accessed on 27 July 2021).

27. https://www.undp.org/sustainable-development-goals (accessed on 27 July 2021).

28. https://www.europarl.europa.eu/ftu/pdf/pl/FTU_2.4.9.pdf (accessed on 27 July 2021). 
